OR-26

\title{
3-PHENACYLURIDINE-DERIVED HYPNOTICS: ANTHOLOGY, STRUCTUREACTIVITY RELATIONSHIPS AND SYNTHESIS OF SEVERAL ACYCLONUCLEOSIDE ANALOGUES
}

\author{
I. A. Novakov, ${ }^{1}$ L. L. Brunilina, ${ }^{1} \underline{\text { I. A. Kirillov }},{ }^{1}$ M. B. Nawrozkij, ${ }^{1}$ M. D. Robinovich, ${ }^{1}$ \\ A. S. Yablokov ${ }^{1,2}$ \\ ${ }^{1}$ Volgograd State Technical University, 28 Lenin Ave., Volgograd, 400005, Russia. \\ ${ }^{2}$ Research Institute of Hygiene, Toxicology and Occupational Pathology, 12 Zemlyachki St., \\ Volgograd, 400048, Russia. \\ E-mail: kirillow.vania@yandex.ru
}

\begin{abstract}
Since the mid 1980-th a number of structurally diverse 3-phenacyluridine [1] analogues have been studied due to their soporophic properties, representing an intriguing alternative to convenient barbiturate and benzodiazepine-derived hypnotics. It was shown, that the proper stereoconfiguration of the C-2' atom of the ribosyl moiety [2-4], as well, as unsubstituted C-5 uracil [5] position are crucial for their hypnotic activity. Noteworthy, that the studied compounds showed their pharmacological properties only after intracerebellar injection to mice. In order to prepare less sterically complex and more lypophilic analogues of the above, synthesis of acetates of the corresponding acyclonucleosides, carrying phenacyl, amethylphenacyl and [(phenylsulfanyl)methyl] moieties at $N^{3}$-position of the uracil ring was accomplished:
\end{abstract}

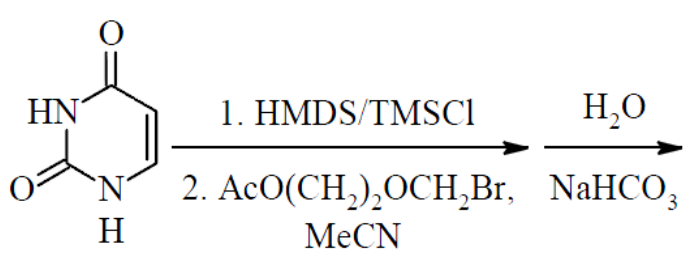

$\mathrm{Ar}=\mathrm{Ph}, 4-\mathrm{MeOC}_{6} \mathrm{H}_{4}, 4-\mathrm{FC}_{6} \mathrm{H}_{4}, \mathrm{R}=\mathrm{H}, \mathrm{X}=\mathrm{C}(\mathrm{O}), \mathrm{Hal}=\mathrm{Br} ; \mathrm{Ar}=$ $\mathrm{Ph}, 4-\mathrm{MeOC}_{6} \mathrm{H}_{4}, \mathrm{R}=\mathrm{CH}_{3}, \mathrm{X}=\mathrm{C}(\mathrm{O}), \mathrm{Hal}=\mathrm{Br} ; \mathrm{Ar}=4-\mathrm{FC}_{6} \mathrm{H}_{4}, \mathrm{R}=$ $\mathrm{CH}_{3}, \mathrm{X}=\mathrm{S}$, Hal $=\mathrm{Cl}$.

These substances are under in vivo evaluation at present.

\section{References}

1. The Potent Depressant Effects of $N^{3}$-Phenacyluridine in Mice / S. Kondo, J. Kuze, T. Kimura, K. Watanabe // Biological and Pharmaceutical Bulletin. - 1994. - Vol. 17, No. 4. - P. 514-516.

2. Hypnotic action of $N^{3}$-substituted arabinofuranosyluracils on mice / T. Kimura, S. Yao, K. Watanabe, S. Kondo [et al.] // Chemical and Pharmaceutical Bulletin. - 2001. - Vol. 49, No. 1. - P. 111-113.

3. Central nervous system depressant effects of $N^{3}$-substituted derivatives of deoxyuridine in mice / T. Kimura, J. Kuze, S. Teraoka, K. Watanabe [et al.] // Biological and Pharmaceutical Bulletin. - 1996. - Vol. 19, No. 1. - P. 142-145.

4. Synthesis and Hypnotic and Anti-Human Immunodeficiency Virus-1 Activities of $N^{3}$-Substituted 2'-Deoxy2'fluorouridines / Y. Sato, K. Utsumi, T. Maruyama, T. Kimura [et al.] // Chemical and Pharmaceutical Bulletin. - 1994. - Vol. 42, No. 3. - P. 595-598.

5. Preparation and Pharmacological Evaluation of $N^{3}$-Substituted Thymidine Derivatives as Central Depressants / T. Kimura, Y.Tateoka, I. K. Ho, I. Yamamoto [et al.] // Chemical and Pharmaceutical Bulletin. - 1993. - Vol. 41. No. 6. - P. 1180-1182. 